\title{
THE QUARRY WASTE "RAVANETI" IN SICILY: GEOMORPHOLOGIC ASPECT
}

\author{
Vincenzo Liguori, Savina Buscemi and Giorgio Manno \\ Dipartimento di Ingegneria Strutturale e Geotecnica Facoltà di Ingegneria Palermo Sicily - (Italy) \\ e-mail: liguori@diseg.unipa.it
}

\begin{abstract}
In Sicily, the activity of extraction and workmanship represents an important productive sector that is substantially concentrated in the two poles; Catania (where the lava stone is worked) and Trapani (in the marble compartment of Custonaci) where over ten types of workable sedimentary and polished rocks are extracted. This area is Particularly characterized by the presence of mesozoic carbonatic rocks used as valuable stony materials "marbles" that are formed in environment of carbonatic and pelagic platforms (seamounts), during an active tectonic regime. They were formed, therefore, in a geologic context which has encouraged their formation with a brecciate texture, of polycyclic origin and with extremely varying colors. In the quarries of the area of Custonaci ( $75 \%$ of the regional production), there are mainly extracted litho types clear ivory colored, variegated with various veins of light brown, distinguished in "Perlato", "Perlatino of Sicily", "Avorio Venato", "Botticino", according to the more or less heterogeneous and fine grain. To these ones it must be added "Nerello" a dark grey colored rock with yellow veins.
\end{abstract} As a consequence of the intense quarrying protracted in time, the marble basin of Custonaci is characterized by enormous volumes of discarded deposits coming from cultivation (in some cases they can reach dozens of hectares), called quarry waste ("ravaneti") which are flowed into the slopes next to the areas of quarrying. The quarries cause dangers to the integrity of the Geomorphology in the area of Custonaci. This happens not only in terms of deep and superficial water pollution, or even in terms of atmospheric contamination due to dust dispersion, but, more significantly, the intense quarrying and the constant removal of rocky materials naturally provoke irreversible alterations of the morphology of the mountain profiles and its plains. Standing on the quarrying areas, quarry waste ("ravaneti"), in addition, represents one of the principal sources of hydro geological instability, provoking rock-falls and debris flow. In the past few years, many quarry waste have provoked events of landslide in terms of mass transports of detrital deposit. During the accumulation of the quarry waste, the deposits are initially placed according to its own angle of repose, generally elevated with values up to $40-45^{\circ}$ and granulometric percentages of: rubble $30 \%$, grit $25 \%$ and sand $45 \%$. Their disposition, during their accumulation, is a consequence of their surface roughness irregular shapes and dimensions. The continuous feed from the top leads to the modification of the scarp 
dimensions and steepness, so the angle of repose of them quarry waste is often overcome. What is said involves the partial gravitative mobilization along the slope of quarry waste, with the tendency to have the coarsest elements towards the groin of the slope, as it happens for the strata of the debris cones. These sudden gravitative events are more frequent in the periods of great rainfall and when thinner materials are brought inside the quarry waste. There are conditions of insecurity, therefore, for the infrastructures surrounding the areas of mining and a continuous change of the Geomorphology of the places. Such a huge quantity of quarry waste represents a primary resource of good quality loose stony materials. They could be separated and charted according to the following five parameters: typology, granulometry, permeability, activity and drawing areas. Drawing these materials could represent an environmental and Geomorphologic redevelopment of the sites and it represents a partial management of the marble fields. The results of the investigations made on this quarry waste suggested the possibility of exploitation as inert materials for road and railway construction and other infrastructural projects, as also shown by the analytical data of the laboratory experiments. Moreover, "ravaneti" are also suitable to be used as material for the reclamation of disused and abandoned quarries. All of this represents a favorable result from an environmental point of view as it would get the advantage to reduce the demand of cultivation of new loan quarries and it would be possible to reemploy some quarry waste, avoiding their deposition in areas next to the site of quarrying and modifying the morphological configuration of the territory.

Key words: quarry waste (ravaneti), geomorphology, environment geology, quarry, environment management.

\section{Introduction}

In Sicily the marble compartment directly affects about 500 companies between quarries, sawmills and workshops, with over 5,000 employees. These figures are additional figures involved in related, such as shipping companies, handling, marketing, production of accessories for working stone materials. On the basis of information confirming the importance it holds this production within the regional economic reality. The mining activities in Sicily is a strength for the economy. In fact is, the Sicily is in second place after Carrara. 


\begin{tabular}{|l|l|c|c|c|c|}
\hline \multicolumn{1}{|c|}{ Trade name } & \multicolumn{1}{|c|}{ Litology } & $\begin{array}{c}\text { Volumetric } \\
\text { mass } \\
\mathbf{g} / \mathbf{c m}^{3}\end{array}$ & $\begin{array}{c}\text { Resistance to } \\
\text { simple } \\
\text { compression } \\
\mathbf{K g} / \mathbf{c m}^{2}\end{array}$ & $\begin{array}{c}\text { Coefficent } \\
\text { of water } \\
\text { adsorption }\end{array}$ & $\begin{array}{c}\text { Breaking } \\
\text { strength } \\
\text { under } \\
\text { compression } \\
\text { after frezeeng } \\
\text { Kg/cm }\end{array}$ \\
\hline Avorio venato & $\begin{array}{l}\text { Limestone with fossils, } \\
\text { Jurassic - Cretaceous } \\
\text { early }\end{array}$ & 2.65 & 1290 & 0.28 & 1140 \\
\hline Botticino & $\begin{array}{l}\text { Compact and cristalline } \\
\text { limestone, Cretaceous }\end{array}$ & 2.67 & 1160 & 0.33 & 1040 \\
\hline Brecciato & $\begin{array}{l}\text { Limestone breccias, Trias } \\
\text { upper }\end{array}$ & 2.61 & 1088 & 0.21 & - \\
\hline Libeccio & Bioclastic limestone & 2.70 & 1265 & 0.12 & 1054 \\
\hline $\begin{array}{l}\text { Nerello di } \\
\text { Custonaci }\end{array}$ & $\begin{array}{l}\text { Bioclastic limestone } \\
\text { Mesozoic - Miocene early }\end{array}$ & 2.61 & 1088 & 0.21 & 1045 \\
\hline Perlato di Sicilia & $\begin{array}{l}\text { Limestone with fossils, } \\
\text { Cretaceous early }\end{array}$ & 2.68 & 1250 & 0.32 & 125 \\
\hline $\begin{array}{l}\text { Pietra dorata di } \\
\text { Mistretta }\end{array}$ & Quarz sandstone & 2.45 & 130 & 1.40 & 887.40 \\
\hline $\begin{array}{l}\text { Arenaria grigia } \\
\text { dei Nebrodi }\end{array}$ & Quarz sandstone, grey & 2.60 & 1040 & 1.82 & 128 \\
\hline $\begin{array}{l}\text { Pietra lavica } \\
\text { dell'Etna }\end{array}$ & Lavic Stone & 2.18 & 133 & 2.74 & 925 \\
\hline Grigio Mirto & Grey Limestone & 2.70 & 935 & 0.12 & 1180 \\
\hline Grgio di Billiemi & Limestone Breccia, grey & 2.71 & 1400 & 0.01 & \\
\hline
\end{tabular}

Table 1: Some sicilian marbles more widespread

A major mining centers is Custonaci will produce about $85 \%$ of Sicilian marble (which corresponds to $15.7 \%$ at national level and to $2.7 \%$ on the world), creating a business average/year over 90 million euros (while the annual turnover / average farm is about 700,000 euros), with an incidence of $48 \%$ on business of the regional compartment and $2.4 \%$ on the national level [1].

The purpose of this study was to highlight what are the environmental issues associated with mining. During the various stages of processing waste are produced. These waste are know as ravaneti and marmettole (sludge processing). They represent today an environmental problem not yet solved.

The ravaneti residues are working with varying dimensions from a few centimeters for meter, which often are built in areas near the quarry side. They are often subject to disruption because their uncontrolled accumulation, trigger landslides and the collapse in a few cases of detrital casting. The marmettola is the mud which is formed during the various stages of manufacture of marbles. The latter have a big impact because often they are released into creating pollution of both surface water that groundwater. In the latter case could trigger a serious process of pollution affecting the water of the territory. It is clear that proper management and disposal of ravaneti and marmettole 
represents is a problem in terms of environmental impact in economic terms. Just think of the amount of ravaneti produced in the basin of mining Custonaci equal to $10-15 \%$ of the material extracted.

\section{The quarry waste - ravaneti}

The process of marble mining generates a considerable amount of waste that reaches the $90 \%$ of the material extracted. This material, is the ravaneto. together with "cocciame" (quarry waste) that originates from the saw cutting of the stone material, is the ravaneto.

The ravaneti are thrown from working square along the sides. In this way they change the landscape. They represent garbage are not allowed to cause the change of the landscape. For this type of disposal is necessary to consider, as primary objectives, the geotechnical stability and safeguarding the environment [2].

This type of garbage is an example of how not to be managed and disposed of the waste quarry; often large portions the deposit, that can be found and yet potentially exploitable, are buried in large quantities of waste.

The ravaneti keeps intact the chemical and mineralogical characteristics of the origin rock. In this way, we can distinguish different types of ravaneto according marble provenance. In Custonaci area there are esteemed stone and their ravaneti have the equal characteristics.

\section{CUSTONACI "RAVANETI" (QUARRY WASTE)}

\begin{tabular}{|l|l}
\hline Chemical composition & $\begin{array}{l}98 \% \text { Calcite } \\
2 \% \text { Dolomite, Davisonite, Illite, Allcharite, Quarz }\end{array}$ \\
\hline
\end{tabular}

\begin{tabular}{|c|c|}
\hline Origin rock & Description \\
\hline Bottcino & Colour: hot ivory, "arabesque" brown in Broccatello variety. \\
\hline Perlato di Sicilia & $\begin{array}{l}\text { Colour: light ivory, "arabesque" brown, with veins of calcite } \\
\text { similar at mother of perl of the shells. The granulometry is } \\
\text { heterogeneous and its aspect is highly polished. }\end{array}$ \\
\hline Avorio Venato & $\begin{array}{l}\text { Colour: ivory, veins brown, with pink tinges and ripetitive iron } \\
\text { insertion of colours gold yellow; structure very compact. In some } \\
\text { areas, has regular greins green and pink reflections. }\end{array}$ \\
\hline Brecciato - Brecciato Rosso & $\begin{array}{l}\text { The grains are angular and with varables colors. The colors are: } \\
\text { brown, pink, red, etc. The grains are immersed in whitish- } \\
\text { reddish matrix and with arenitic size. The structure is very } \\
\text { compact and with little porous. They present with veins of } \\
\text { calcite. }\end{array}$ \\
\hline Libeccio - Libeccio antico & $\begin{array}{l}\text { They present with spotting subarrotondate with light brown color, } \\
\text { a contact with each other and surrounded by an array of color } \\
\text { varies from white to dark reddish-brown; Libeccio old varieties } \\
\text { in the matrix is composed of limestone quality alabaster. }\end{array}$ \\
\hline
\end{tabular}


Table 2: Some sicilian esteemed stone (Custonaci area)

Also according to the size of the prevailing grains constituents the ravaneti recognize the following types.

- Inform ("Informe"): blocks whose irregular shape. They are not workable and then an economic exploitation. The grains have irregular shape with volumes major or equal to $\mathrm{m}^{3}$

- Pieces ("Pezzame"): uniform grains with an average size between $30 \mathrm{~cm}$ and $1 \mathrm{~m}$.

- Stones ("Sassi”): grains with an average size between 5 and $30 \mathrm{~cm}$

- Pieces and Stones (“Pezzame and Sassi”): Grains with prevailing pezzame size (between $30 \mathrm{~cm}$ and $1 \mathrm{~m}$ )

- Mix ("Miscela"): with two or more types

\begin{tabular}{|c|c|c|c|c|}
\hline \multicolumn{4}{|c|}{ Ravaneti - Chemical Caratterization } & \multirow[b]{2}{*}{ Ravaneti - Granulometric curve } \\
\hline Parameters & $\begin{array}{c}\text { Uunit of } \\
\text { measurement }\end{array}$ & $\begin{array}{c}\text { Sample } \\
\text { concentration }\end{array}$ & $\begin{array}{c}\text { Limit } \\
\text { concentration }\end{array}$ & \\
\hline
\end{tabular}

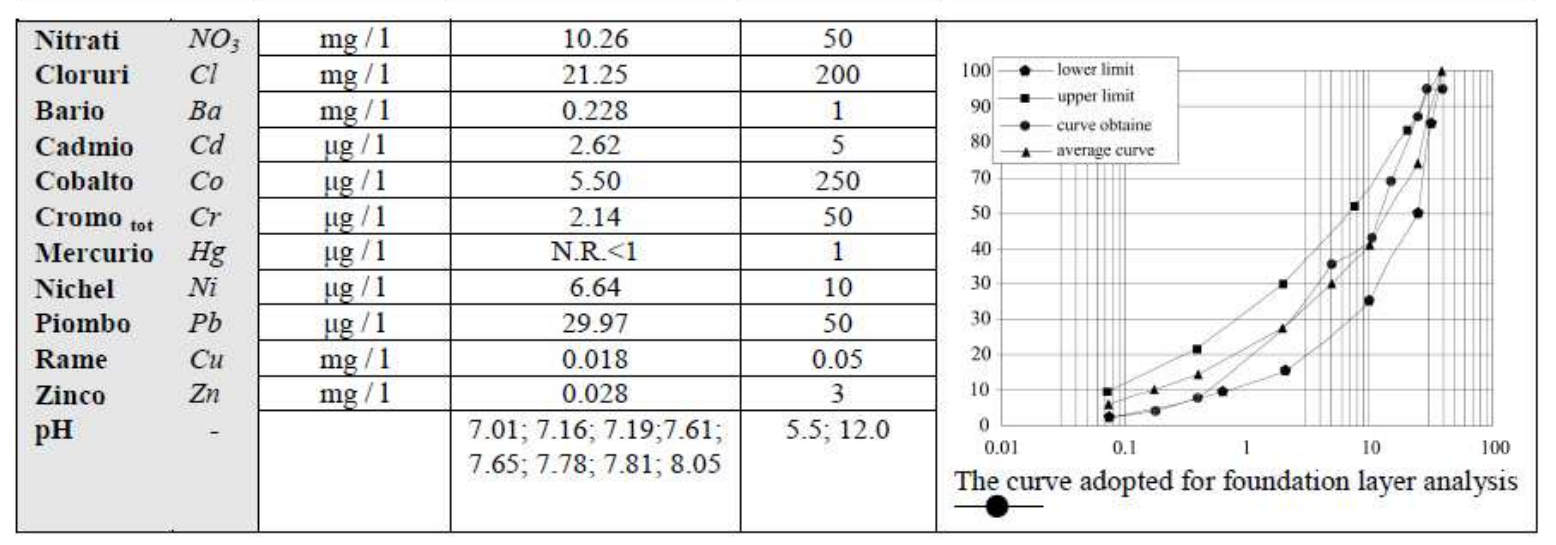

Table 3: Chemical and granulometric caratterization of ravaneti.

The granulometric curve: gravel 30\%, 25\% grit and sand $45 \%$.

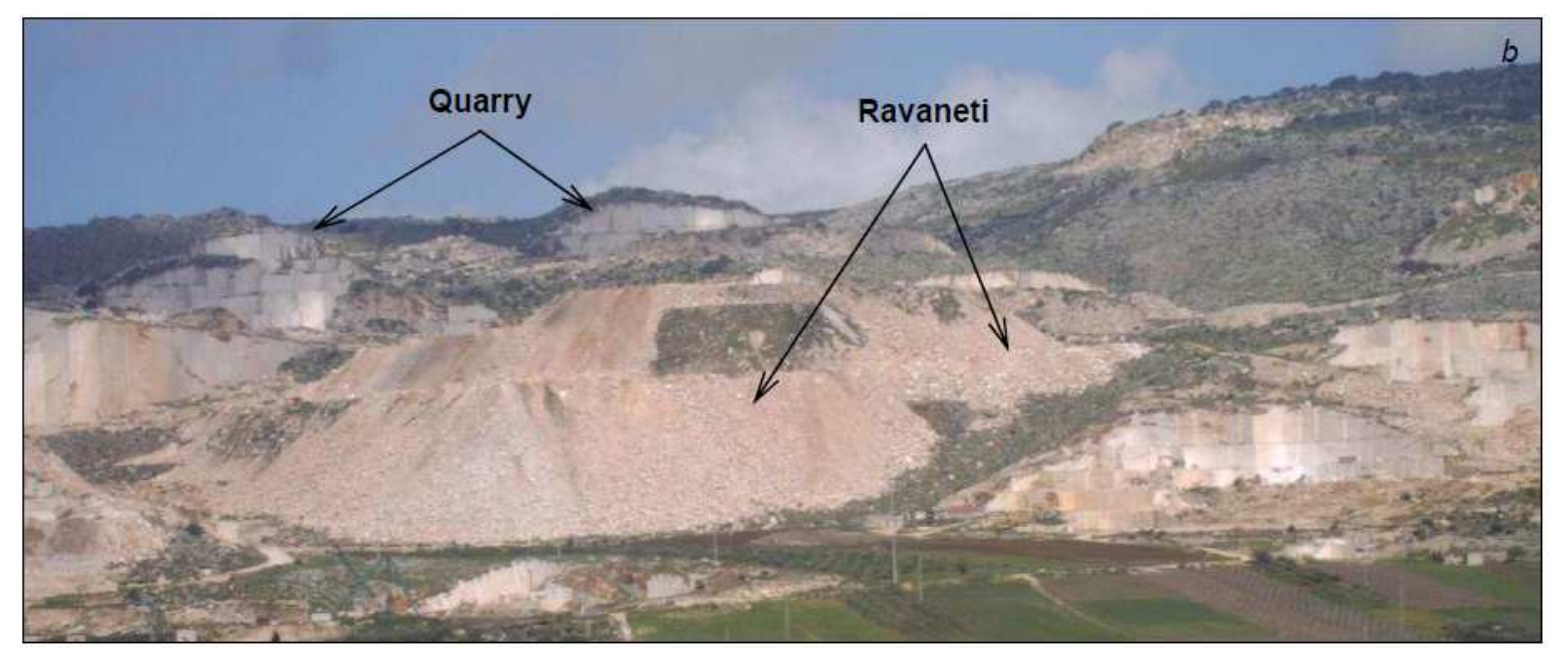

Figure 1a-1b) Quarries in Custonaci (Trapani). 
The production of such waste is not uniform in the region - the mining activities are largely concentrated in localized areas and easily defined. We can estimate that in Sicily is an annual production of marble and stone equal at 900.000 $-1.000 .000 \mathrm{t}$. These numbers is refer to the net production quarrying, net of the waste. In this sector the percentuals are very high with values around $70-75 \%$ (Custonaci marbles) of the extract material. So the bulk of the regional production of waste is concentrated in the Custonaci and that of a - still easily be assessed - the component lost as cut stone is already recovered for the production of aggregates for construction.

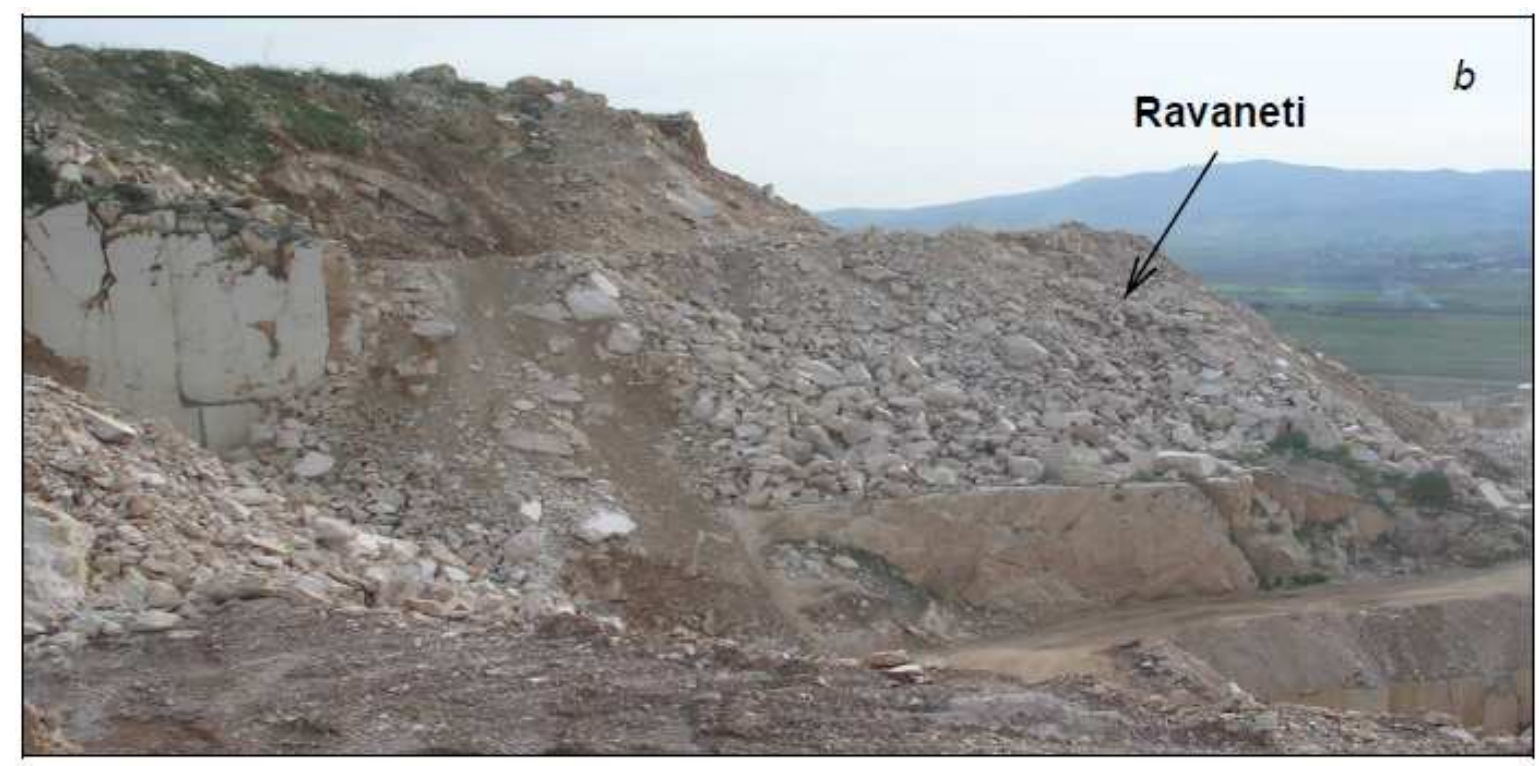

Figure 2 a-b: Ravaneti deposits, Custonaci (Trapani). The deposits is various granulometry.

It should also be taken into account the problem of the temporary storage of waste on the square of quarry. It is because of problems both for the rational exploitation of the deposit, both for the safety of employees working in the quarry. The problems can be introduced total or partial solution if it provides, a correct management of the ravaneti. One could envisage the use of ravaneti as a natural replacement of the construction inert.

The difference quarry, remains intact because the characteristics of the stone from which can be easily used for the production of aggregates. The supply within the mills, therefore, as an alternative primary resource extraction, is the most rational and functional reuse. The ravaneti derives essentially from the process of extraction of stone material is free from the presence of possible contaminants, it is easily retrievable in the field of construction. All tests performed on ravaneti of Custonaci (Trapani) showed that the parameters are within the requirements for the reuse of these materials as background road, because the parameters are: 


\begin{tabular}{|l|c|c|}
\hline \multicolumn{3}{|c|}{ Foundation layer $\left(\mathbf{D}_{\max }<\mathbf{7 1} \mathbf{~ m m}\right)$} \\
\hline & Parameters of capitulate & Parameters obtained \\
\hline Los Angeles Test & $<30 \%$ & $24,96 \%$ \\
\hline $\begin{array}{l}\text { CBR Index } \\
\text { (after 4 days of imbibition with water) }\end{array}$ & $>50 \%$ & 51,78 \\
\hline AASHTO Mod. Test & - & $\begin{array}{c}\mathrm{w}=8 \% \\
\mathrm{~g}_{5}=2.09 \mathrm{~g} \mathrm{~cm}^{3}\end{array}$ \\
\hline
\end{tabular}

Table 4: Physical parameters of sicilian ravaneti

The values obtained by the mixture of inert and that bitumen using ravaneti fall within the limits imposed by the special dedicated to tender specifications and performance. That fact is a result certainly supports the reuse of ravaneto both environmental and industrial because it would fulfill the dual benefit of reducing the demand for cultivation of new quarries loan, and the business of extracting, transforming a cost (reserve remaining) in potential revenue generated from the ravaneti [3].

\section{Geomorphology aspect}

In the formation of a ravaneto, debrises initially have the angle rest of the material, generally rather high (up to about $40-45^{\circ}$ ), depending on the roughness of grains and their irregular shape and size [4]. The grains assortment size falls within the range generally in size from multi-centimetric to metric while the fine fraction is significantly subordinated.

The continuing gravity feed leads to exceed the angle of repose frequently and then the partial redeployment of the material along the slope. Because of this cause the grains at the bottom (nail) of the slope and the finest at the top of the slide. In fact they behave like the detrital cone and detrital layer. The form can often be similar to the one of a detrital cone. The detrital cone has an apical termination as in the case of a ravaneto accumulated in a impluvium or in a riverbed torrential. Their form can be the one of a truncated cone, for example when the area hosts a square manoeuvre. An inactive ravaneto has a good degree of stability, and develops processes of spontaneous renaturalization. The significant aspect of ravaneti is related to its gravitative stability.

In the active ravaneti, fuelled by a cultivation quarry, size and steep slide are continually altered, therefore the material is loose and mobile. In this way the rest angle is exceeded and the material falls down the slope.

When ceased the contributions, inactive ravaneti obtain a greater stability and the cementification processes, can further develop while the superficial stability fosters pedogenesis and renaturalization of areas, with the 
development of vegetation. The granulometric characteristics, the grains roughness and the high permeability generally help reduce the propensity to collapse. However, the safety factor may be especially critical in active or inactive ravaneti for short periods of time. Among the causes of erosion various kinds of landslides may occur, frequently because of collapse or debris flow. Conditions of insecurity and danger for the workers, can exist especially in the ravaneti where a re-use is in progress. In fact the extraction is often performed at the base of the accumulation, with the consequent destabilization of the overlying material. The risk that such a mining methodology involves is further underlined especially if, especially if, the composition and the physical mechanics of storage are not well known. Nowadays ravaneti represent one the main sources of hydro geological risk on quarrying areas. In recent years, many build-up ravaneti have been affected by landslide phenomena represented mainly by mass transport of detritals. A lot of debrises suggest that these accumulation of ravaneti may be affected by "collapse debris flow" description as quick movements of a mixture of detritals, water and air behaving like a viscous fluid. In some areas the pluviometric data recorded concomitantly with of landslides highlighted that $60 \mathrm{~mm}$ of rain (5 hours), with intensity of only $14 \mathrm{~mm} /$ hour are sufficient to start these movements. General studies highlight that, the frequency is increase in recent years of this type of landslide is connected to the introduction of fine material inside the ravaneti [5]. In many cases it is possible to observe, how the detrital body of ravaneti is formed by overlapping layers of a different size, composition and permeability.

Big blocks with a scarce sandy matrix and uniform lump size levels constitute the deeper layer (oldest), while the most superficial layers are formed, along with boulders and blocks of varying sizes, also by a large detritals of fine material (restricted), which decreases the permeability of the accumulation.

\section{Reference}

1 V. Liguori, C. Castiglia, V. Cipolla, V. Cusimano, A. Di Cara., and A. Mascari (1977). Le frane in Sicilia. Bibliografia geologica dal 1906 al 1976.

2 M. La Gennusa, C. Raimondi, G. Rizzo and M. Traverso, (2006). Enviromental impact of marble minino: the case study of a sicilian marble quarry. Proceedings of SETAC Europe - 13th LCA Case Studies Symposium. Germany.

3 F. Corriere, D. Di Vincenzo, T. Giuffrè and D. Ticali (2007). "L'uso del "Ravaneto" nelle costruzioni stradali. In Le Strade, pag. 140-148.

4 V. Liguori, G. Rizzo and M. Traverso, (2008). Marble quarrying: an energy and waste intensive activity in the production of building materials. In Wessex Environmental Economics, Spagna.

5 V. Liguori (1977). La difesa del suolo in Sicilia : aspetti geologici. Il Mediterraneo n. 7/8 - luglio-agosto 
